\title{
Analysis of workplace violence against nursing professionals and possibilities for prevention
}

\author{
Análise da violência no trabalho contra profissionais de \\ enfermagem e possibilidades de prevenção \\ Análisis de la violencia laboral contra profesionales de \\ enfermería y posibilidades de prevención
}

Maiara Bordignon ${ }^{\mathrm{a}, \mathrm{b}}$
Maria Inês Monteiroc

How to cite this article: Bordignon M, Monteiro MI. Analysis of workplace violence against nursing professionals and possibilities for prevention. Rev Gaúcha Enferm. 2021;42:e20190406. doi: https://doi.org/10.1590/19831447.2021 .20190406
Universidade Federal da Fronteira Sul (UFFS), Curso de Graduação em Enfermagem. Chapecó, Santa Catarina, Brasil.

- Universidade do Contestado (UnC), Curso de Graduação em Enfermagem. Concórdia, Santa Catarina, Brasil.

"Universidade Estadual de Campinas (UNICAMP), Faculdade de Enfermagem. Campinas, São Paulo, Brasil.

\section{ABSTRACT}

Objective: To investigate workplace violence against nursing professionals, its relationship with personal, health and work variables, and to know possibilities for prevention.

Method: Descriptive and cross-sectional study, with quantitative approach, conducted with 267 nursing professionals from urgency and emergency units between 2015 and 2017. The Questionnaire of socio-demographic, life style and work and health aspects and Questionnaire on Workplace violence collected data, after submitted to statistical analysis.

Results: $61.6 \%$ reported having been victims of verbal abuse, sexual harassment, or physical violence at work in the last 12 months. Statistically significant relationships were identified between suffering or not violence and personal, health and work variables. Possibilities for prevention were revealed and constituted a multidimensional model.

Conclusion: More than half of the sample reported having suffered workplace violence in the previous year, and possibilities of how to avoid it were revealed to support prevention protocols.

Keywords: Violence. Workplace violence. Work. Health personnel. Nursing.

\section{RESUMO}

Objetivo: Investigar a violência no trabalho dirigida a profissionais de enfermagem, sua relação com variáveis pessoais, de saúde e trabalho, e conhecer possibilidades de prevenção.

Método: Estudo descritivo, transversal e de abordagem quantitativa com 267 profissionais de enfermagem de unidades de pronto atendimento e emergência hospitalar entre 2015 e 2017. 0 Questionário sobre Dados Sociodemográficos, Estilo de Vida, Aspectos de Saúde e Trabalho e o Questionário de violência no trabalho coletaram dados, posteriormente submetidos a análises estatísticas.

Resultados:61,6\% relataram ter sido vítima de abuso verbal, assédio sexual ou violência física no trabalho nos últimos 12 meses. Identificou-se relações estatisticamente significantes entre sofrer ou não violência e variáveis pessoais, de saúde e trabalho. Indicou-se possibilidades de prevenção, que constituíram um modelo multidimensional.

Conclusões: Mais da metade da amostra relatou ter sofrido violência no trabalho no ano anterior, e possibilidades de como evitá-la foram reveladas em prol de protocolos de prevenção.

Palavras-chave: Violência. Violência no trabalho. Trabalho. Pessoal de saúde. Enfermagem.

\section{RESUMEN}

Objetivo: Investigar la violencia laboral dirigida a profesionales de enfermería, su relación con variables personales, de salud y laborales, y conocer las posibilidades de prevención.

Método: Estudio descriptivo, transversal y cuantitativo con 267 profesionales de enfermería de unidades de urgencia y emergencia entre 2015 y 2017. El Cuestionario sobre datos sociodemográficos, estilo de vida, salud y aspectos laborales y el Cuestionario sobre violencia laboral recopilaron los datos, que luego se sometieron a análisis estadístico.

Resultados: $61.6 \%$ informó haber sido víctima de abuso verbal, acoso sexual o violencia física en el trabajo en los últimos 12 meses. Se identificaron relaciones estadísticamente significativas entre suffir o no violencia y variables personales, de salud y laborales. Se indicaron posibilidades de prevención, que constituyeron un modelo multidimensional.

Conclusión: Más de la mitad de la muestra informó haber sufrido violencia en el lugar de trabajo en el año anterior, y posibilidades de cómo evitarla fueron reveladas a favor de los protocolos de prevención.

Palabras clave: Violencia. Violencia laboral. Trabajo. Personal de salud. Enfermería. 


\section{口INTRODUCTION}

Workplace violence is recognized internationally as an occupational risk for health professionals and has been a factor of concern in several nations ${ }^{(1-2)}$. Data demonstrate that the risk of these professionals being exposed to physical and non-physical violence in the workplace is significant and varies according to the professional category and sector(2). Nurses, nursing technicians and doctors are generally the biggest victims, as are professionals who work in psychiatric and emergency units ${ }^{(2-4)}$.

Studies conducted in Brazil have revealed significant rates of violence against health professionals ${ }^{(3,5)}$. In some cases, the proportion of victims of violence is approximately half of the workers surveyed, when it does not exceed this number ${ }^{(3,5)}$. These events transcend the Brazilian geographical barriers when they occur in different regions of the country in an expressive way ${ }^{(3,5)}$. In this sense, research identified that about $80 \%$ of the nursing technicians who worked in two psychiatric hospitals in Minas Gerais reported having some experience in relation to physical aggression at work ${ }^{(5)}$. In another study ${ }^{(3)}$, approximately $50 \%$ of health professionals who worked in a hospital in Rio Grande do Sul had been exposed to verbal abuse at work in the previous year and, of these, $83 \%$ considered such situations to be typical in their work environment. In the same study ${ }^{(3)}, 2.5 \%$ of the professionals had suffered sexual harassment at work in the last year, and the victims suffered this form of violence repeatedly, that is, more than three times in the previous year.

Furthermore, it is evident in the literature that victims of workplace violence are susceptible to health problems, such as psychological consequences and physical injuries ${ }^{(1-2,5-8)}$. As a consequence, violence can affect the institution and the provision of quality services, by generating costs, impacting the workforce and professional performance, in addition to its potential to contribute to family, social and financial difficulties ${ }^{(1,6-9)}$. Despite these numbers and consequences, the lack of policies at the governmental and institutional levels to prevent workplace violence is real in several countries and may be related to the need to understand how it is possible to avoid it ${ }^{(1-2)}$. In fact, the implementation of team protection strategies is essential to prevent health professionals from continuing to be victims of workplace violence in Brazil and in the world $d^{(1,6,8)}$.

Thus, the present study aimed to investigate workplace violence against nursing professionals, its relationship with personal, health and work variables, and to know possibilities for prevention.

\section{$\square$ METHOD}

Descriptive study, cross-sectional with a quantitative approach, conducted with 267 nursing professionals (72 nurses; and 195 nursing technicians or assistants (104 technicians and 91 assistants)) who worked in public urgency and emergency units, four of which emergency care in a city in the interior of the State of São Paulo-SP, a hospital emergency unit in the same city, and two emergency care units in a city in the interior of the State of Santa Catarina-SC. Therefore, the research involved seven health units linked to three different institutions. The study was comprehensive, evaluating different elements related to worker health ${ }^{(10)}$ and, in this article, results are highlighted regarding the characteristics and factors associated with workplace violence, as well as possibilities for preventing this violence.

For the composition of the sample, the following inclusion criteria were considered: nursing professional (nurse, technician, and assistant) with working time in the units of at least three months. Professionals in disagreement with these criteria, who did not accept the invitation to participate and who were away from work due to vacation or leave during data collection, did not participate in this present study.

The minimum sample size was defined by means of a sample calculation that used parameters $p$ proportion of 0.50 , level of significance and error of $5 \%$. For the constitution of the sample, the probabilistic sampling scheme was assumed, which included random sampling of professionals and stratification by unit and categories (i-nurse; ii-technician or assistant). The random sample was carried out by assigning a number to each professional, with subsequent generation of a list of numbers from computer resources. This list was followed to invite professionals. With the stratification it sought to ensure proportionality in the sample, according to the number of professionals in each unit and category of activity.

Data collection was carried out from April 2015 to January 2017, at the professionals' workplace, by the first author. For this, the following instruments were used: Questionnaire of socio-demographic, life style and work and health aspects (QSETS) ${ }^{(11)}$ and Questionnaire on Workplace violence ${ }^{(12)}$. Some professionals filled out the questionnaires individually and turned to the researcher in cases of doubt, and others requested her presence during the filling.

The QSETS was used to obtain personal data and related to health and work ${ }^{(11)}$. This instrument has been applied in different researches on health and work over two decades, which contributes to its improvement and validity (11). 
The'generations'variable was calculated from the year of birth obtained by QSETS ${ }^{(11)}$, and the following characteristics were considered for classification: baby boomers (individuals born from 1946 to 1964), generation X (1965-1980) and millennials (1981-2000)(13). This variable was inserted in the study considering that the professionals' experiences and perceptions regarding the environment can vary between generations ${ }^{(14)}$.

To identify the frequency of workplace violence and characterize the cases, it was used a questionnaire that assess the occurrence of workplace violence in the 12 months prior to data collection, with three forms of violence being specifically assessed: verbal abuse, physical violence and sexual harassment, conceptually defined ${ }^{(12)}$. The instrument consists of five sections that assess the occurrence of each of the three types of violence, and two sections allow to report whether other types of violence have been suffered and the opinion of professionals regarding prevention ${ }^{(12)}$. This measure was considered valid based on the apparent validity process with experts ${ }^{(12)}$. The answer options include categorical formats that make it possible to know whether or not the professionals suffered workplace violence in the previous year and, if so, to present characteristics in relation to the last time they remember having suffered ${ }^{(12)}$. It was considered victim those professionals who reported having suffered at least once verbal abuse, physical violence or sexual harassment at workplace; and these three forms were considered to define how many types of violence have been suffered in the last 12 months ${ }^{(10)}$.

Data were inserted into Microsoft Excel ${ }^{\circ}$ databases, and those with a quantitative character were analyzed using the Statistical Package for the Social Sciences (SPSS) for Windows $^{\circ}, 20.0$ e 24.0. The qualitative data of the open question about violence prevention measures were analyzed by the researcher in Microsoft Excel ${ }^{\circ}$, with definition of the number of reports. The schematic model designed to bring together the dimensions of violence prevention was developed with support from Microsoft PowerPoint?.

Quantitative data were analyzed using descriptive statistics that allowed to highlight the absolute frequency and proportion for the categorical variables studied. Statistical tests were applied to verify statistically significant relationships between the variable'workplace violence'and personal, health and work variables. In this sense, the Chi-square test or Fisher's Exact test was used to analyze the association between qualitative variables, and the Mann-Whitney test for comparison between groups regarding medians. The Mann-Whitney test was applied considering that the data were not adherent to the normal distribution according to the Kolmogorov-Smirnov or Shapiro-Wilk tests. In the present study, it was assumed a significance level of p-value of less than 0.05 .

The study was approved by the University's Research Ethics Committee under statements number 977.885/2015 and $1.600 .763 / 2016$. Resolution $466 / 2012$ of the National Health Council was respected. The professionals who were invited and agreed to participate in the study registered their consent in the Free and Informed Consent Form and had their privacy ensured through nameless questionnaires and the allocation of a number to each participant during the constitution of the database.

\section{RESULTS}

Most of the professionals were female (79.8\%), and most of the sample consisted by professionals from the emergency care units-SP (51.3\% of the sample) in relation to the SC units (16.5\%) and hospital unit (32.2\%).

From 263 respondents, $61.6 \%$ reported having suffered workplace violence in the last year, and $17.9 \%$ (46/257) suffered at least two types of violence among those assessed (Table 1).

From 265 professionals, 60\% ( $n=159)$ reported having suffered verbal abuse at work in the last 12 months, and 40.8\% suffered four times or more (out of 157 respondents). The patient was the main aggressor in this type of violence; and verbal abuse was often not recorded, and victims were not helped (Table 1).

Regarding sexual harassment at work $6.1 \%(n=16)$ of the 263 respondents indicated that they had suffered this violence in the previous year, and $33.3 \%$ suffered four times or more (5/15). In this case, patients, co-workers, and bosses were the main aggressors. The events took place mainly at night and in the morning. Most of the time the victim did not receive assistance and there was no record of the harassment (Table 1).

The proportion of victims of physical violence was $15.8 \%$ $(n=41)$ among 259 respondents, and 56.4\% (22/39) suffered at least twice in the last year. There was a predominance of physical violence without a weapon and perpetrated by the patient. Most of the victims received no assistance and there was no record of the violent event (Table 1).

It was revealed that in $93.8 \%$ of the cases the perpetrators of sexual harassment were male and the victim was female. In physical violence, a significant part of the episodes was generated by male aggressors towards women (Figure 1). 
Table 1 - Characteristics of workplace violence events. Campinas/SP, Chapecó/SC, 2015 to 2017 (n=267)

\begin{tabular}{|c|c|c|c|c|c|c|c|}
\hline \multirow[t]{2}{*}{ Variable } & & \multicolumn{2}{|c|}{$\begin{array}{l}\text { Verbal abuse } \\
(n=159)\end{array}$} & \multicolumn{2}{|c|}{$\begin{array}{l}\text { Sexual harass- } \\
\text { ment }(n=16)\end{array}$} & \multicolumn{2}{|c|}{$\begin{array}{l}\text { Physical violence } \\
\text { ( } n=41)\end{array}$} \\
\hline & & $\mathbf{n}$ & $\%$ & $\mathbf{n}$ & $\%$ & $\mathbf{n}$ & $\%$ \\
\hline Occurred in the studied unit & No & 7 & 4.4 & 2 & 12.5 & 2 & 4.9 \\
\hline no inf. $1^{*}$ & Yes & 151 & 95.6 & 14 & 87.5 & 39 & 95.1 \\
\hline Use of object & With weapon & - & - & - & - & 1 & 2.5 \\
\hline no inf. $1^{* *}$ & Without weapon & - & - & - & - & 39 & 97.5 \\
\hline Aggressor - chief $^{\dagger}$ & No & 141 & 89.8 & 11 & 68.8 & 41 & 100.0 \\
\hline no inf. $2^{*}$ & Yes & 16 & 10.2 & 5 & 31.3 & 0 & 0.0 \\
\hline $\begin{array}{l}\text { Aggressor - co-worker (internal or } \\
\text { external to the unit) }\end{array}$ & No & 128 & 81.5 & 10 & 62.5 & 39 & 95.1 \\
\hline no inf. $2^{*}$ & Yes & 29 & 18.5 & 6 & 37.5 & 2 & 4.9 \\
\hline Aggressor - patient relatives ${ }^{\dagger}$ & No & 82 & 52.2 & 16 & 100.0 & 36 & 87.8 \\
\hline no inf. $2^{*}$ & Yes & 75 & 47.8 & 0 & 0.0 & 5 & 12.2 \\
\hline Aggressor - patient $^{\dagger}$ & No & 58 & 36.9 & 9 & 56.3 & 3 & 7.3 \\
\hline no inf. $2^{*}$ & Yes & 99 & 63.1 & 7 & 43.8 & 38 & 92.7 \\
\hline Aggressor - general public ${ }^{\dagger}$ & No & 111 & 70.7 & 15 & 93.8 & 35 & 85.4 \\
\hline no inf. $2^{*}$ & Yes & 46 & 29.3 & 1 & 6.3 & 6 & 14.6 \\
\hline & Morning & 36 & 23.1 & 7 & 43.8 & 14 & 34.1 \\
\hline Shift of occurrence & Afternoon & 45 & 28.8 & 2 & 12.5 & 12 & 29.3 \\
\hline no inf. $3^{*}$ & Night & 70 & 44.9 & 7 & 43.8 & 15 & 36.6 \\
\hline & 2 shifts or more & 5 & 3.2 & - & - & - & - \\
\hline Received assistance & No & 122 & 78.7 & 13 & 81.3 & 34 & 87.2 \\
\hline no inf. $4^{*}, 2^{* *}$ & Yes & 33 & 21.3 & 3 & 18.8 & 5 & 12.8 \\
\hline Recorded the incident & No & 128 & 81.5 & 15 & 93.8 & 35 & 85.4 \\
\hline no inf. $2^{*}$ & Yes & 29 & 18.5 & 1 & 6.3 & 6 & 14.6 \\
\hline
\end{tabular}

Source: Research data, 2015-2017.

no inf:. Without information. "Missing data for cases of verbal abuse. "Missing data for cases of physical violence. "The professional could indicate more than one option. 


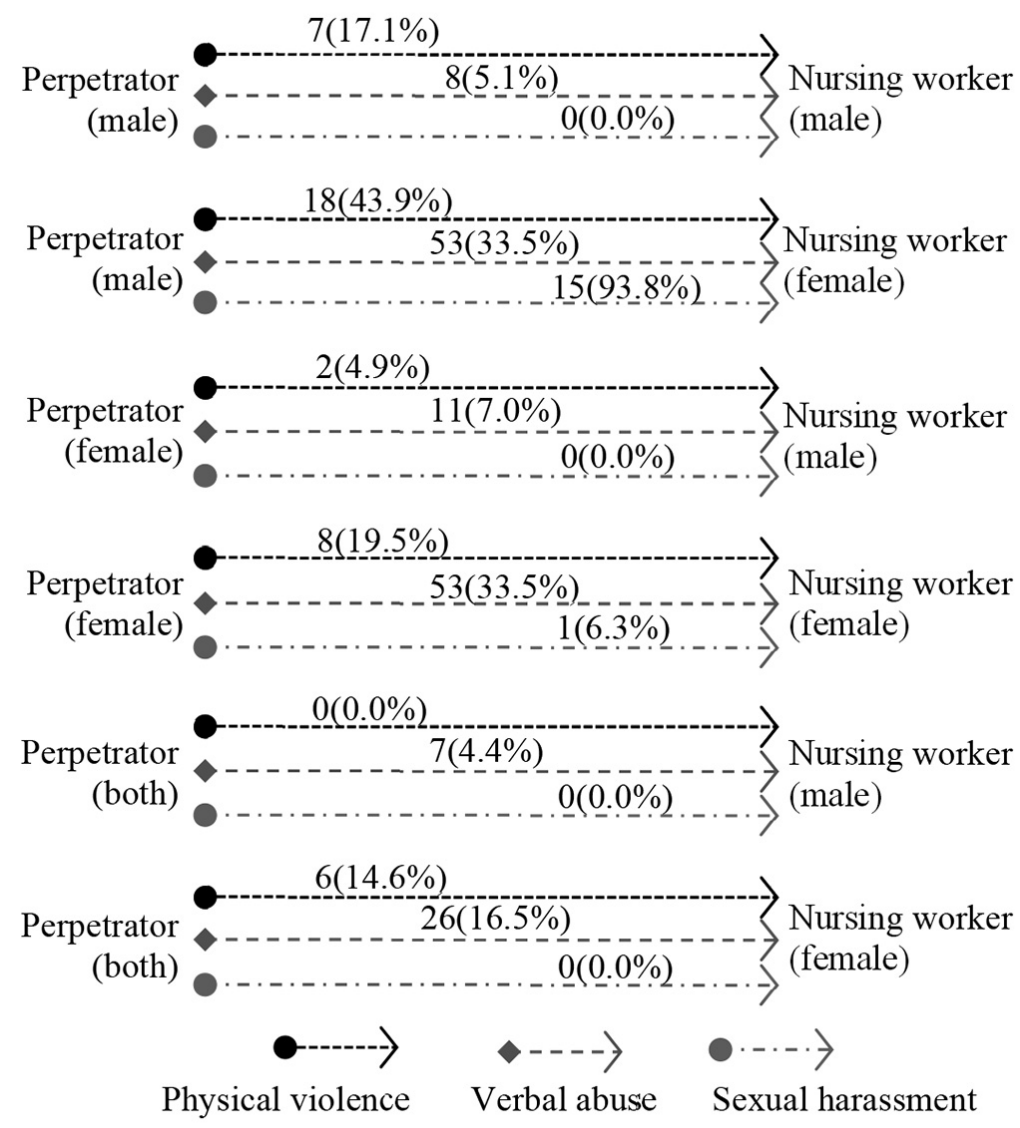

Figure 1 - Analysis involving the gender of the aggressor and the victim. Campinas/SP, Chapecó/SC, 2015 to 2017. (n=267)* Source: Research data, 2015-2017.

*No information on verbal abuse $(n=1)$

Statistical analysis revealed that'workplace violence'was associated in a statistically significant way with the variables: worker's gender, age group, generations, health problem in the last 15 days and sleeping well after work (Table 2).

Specifically to the types of violence, an association with statistical significance was identified between having suffered or not verbal abuse at work and the variables: worker's gender, education, health problem in the last 15 days, feeling tired and/or discouraged after work and sleep well after work. In sexual harassment, an association was observed with the worker's gender, education, generations, and satisfaction with current life; and, in physical violence, with age and generations (Table 2).

An statistically significant association was found between 'having suffered or not verbal abuse' and 'function' $(p=0.0116)$, and nurses reported a higher proportion of abuse (71.4\%) than technicians/assistants (54\%), considering only the cases of violence that happened in the studied units. In physical violence, the association was observed with the workplace ( $p=0.0269$ ). It was revealed that victims of workplace violence had a lower median age than non-victims $(p=0.0045)$. Similarly, this result was found among victims of verbal abuse $(p=0.0103)$, sexual harassment $(p=0.0096)$ and physical violence $(p=0.0071)$.

It is also worth noting that victims of workplace violence had a higher level of stress than non-victims, considering the medians of stress ( $p=0.0203$ ). A similar result was observed among victims of verbal abuse $(p=0.0266)$ and physical violence $(p=0.0235)$.

The professionals indicated measures that they considered favorable for the prevention or reduction of workplace violence. These measures together with the researchers'perception constituted a schematic model with ten dimensions that articulate with each other (Figure 2). 
Table 2 - Personal, health and work characteristics associated with variables of workplace violence. Campinas/SP, Chapecó/ SC, 2015 to 2017. $(n=267)$

\begin{tabular}{|c|c|c|c|c|c|c|}
\hline \multirow{3}{*}{\multicolumn{2}{|c|}{ Variable }} & \multicolumn{4}{|c|}{ Has suffered Workplace violence } & \multirow{3}{*}{ p-value } \\
\hline & & \multicolumn{2}{|c|}{ No } & \multicolumn{2}{|c|}{ Yes } & \\
\hline & & $\mathbf{n}$ & $\%$ & $\mathbf{n}$ & $\%$ & \\
\hline \multirow{2}{*}{$\begin{array}{l}\text { Gender } \\
\text { (no inf. 4) }\end{array}$} & Female & 74 & 35.4 & 135 & 64.6 & $0.0494^{*}$ \\
\hline & Male & 27 & 50.0 & 27 & 50.0 & \\
\hline \multirow{4}{*}{$\begin{array}{l}\text { Age group (in years) } \\
\text { (no inf. 9) }\end{array}$} & $<30$ & 9 & 21.4 & 33 & 78.6 & $0.0448 *$ \\
\hline & 30 to 39 & 37 & 37.0 & 63 & 63.0 & \\
\hline & 40 to 49 & 33 & 44.0 & 42 & 56.0 & \\
\hline & 50 or more & 20 & 48.8 & 21 & 51.2 & \\
\hline \multirow{3}{*}{$\begin{array}{l}\text { Generations } \\
\text { (no inf. 19) }\end{array}$} & Baby boomers & 19 & 50.0 & 19 & 50.0 & $0.0431 *$ \\
\hline & Generation X & 48 & 42.1 & 66 & 57.9 & \\
\hline & Millennials & 28 & 29.2 & 68 & 70.8 & \\
\hline \multirow{2}{*}{$\begin{array}{l}\text { Health problem last } 15 \text { days } \\
\text { (no inf. } 6 \text { ) }\end{array}$} & No & 85 & 41.7 & 119 & 58.3 & $0.0186^{*}$ \\
\hline & Yes & 14 & 24.6 & 43 & 75.4 & \\
\hline \multirow{3}{*}{$\begin{array}{l}\text { Sleep well after work } \\
\text { (no inf. 5) }\end{array}$} & No & 15 & 26.8 & 41 & 73.2 & $0.0414^{*}$ \\
\hline & Yes & 86 & 41.7 & 120 & 58.3 & \\
\hline & \multicolumn{6}{|c|}{ Has suffered verbal abuse at work } \\
\hline \multirow{2}{*}{$\begin{array}{l}\text { Gender } \\
\text { (no inf. 2) }\end{array}$} & Female & 78 & 37.0 & 133 & 63.0 & $0.0463^{*}$ \\
\hline & Male & 28 & 51.9 & 26 & 48.1 & \\
\hline \multirow{4}{*}{$\begin{array}{l}\text { Schooling } \\
\text { (no inf. 4) }\end{array}$} & Up to complete technician & 46 & 52.3 & 42 & 47.7 & $0.0362 *$ \\
\hline & Incomplete higher education & 16 & 33.3 & 32 & 66.7 & \\
\hline & Complete higher education & 25 & 35.2 & 46 & 64.8 & \\
\hline & Postgraduate & 18 & 32.1 & 38 & 67.9 & \\
\hline \multirow{2}{*}{$\begin{array}{l}\text { Health problem last } 15 \text { days } \\
\text { (no inf. 4) }\end{array}$} & No & 89 & 43.2 & 117 & 56.8 & $0.0210^{*}$ \\
\hline & Yes & 15 & 26.3 & 42 & 73.7 & \\
\hline \multirow{2}{*}{$\begin{array}{l}\text { Tired and/or discouraged } \\
\text { after work (no inf. 15) }\end{array}$} & No & 47 & 47.5 & 52 & 52.5 & $0.0420 *$ \\
\hline & Yes & 53 & 34.6 & 100 & 65.4 & \\
\hline
\end{tabular}


Table 2 - Cont.

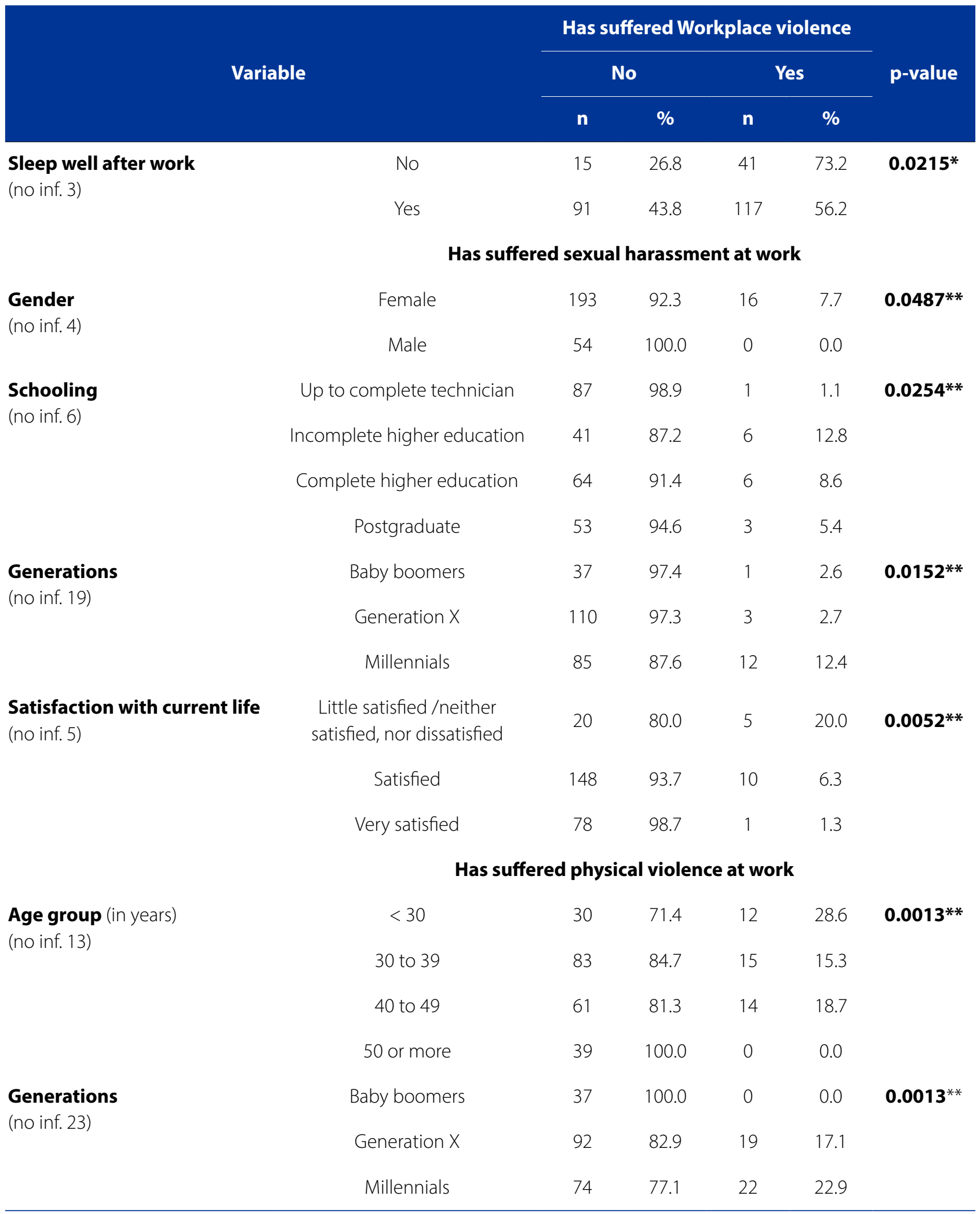

Source: Research data, 2015-2017,

${ }^{*}$ p-value by the Chi-square test. ${ }^{* *}$ p-value by Fisher's exact test.

no inf.: missing data in the analysis. 


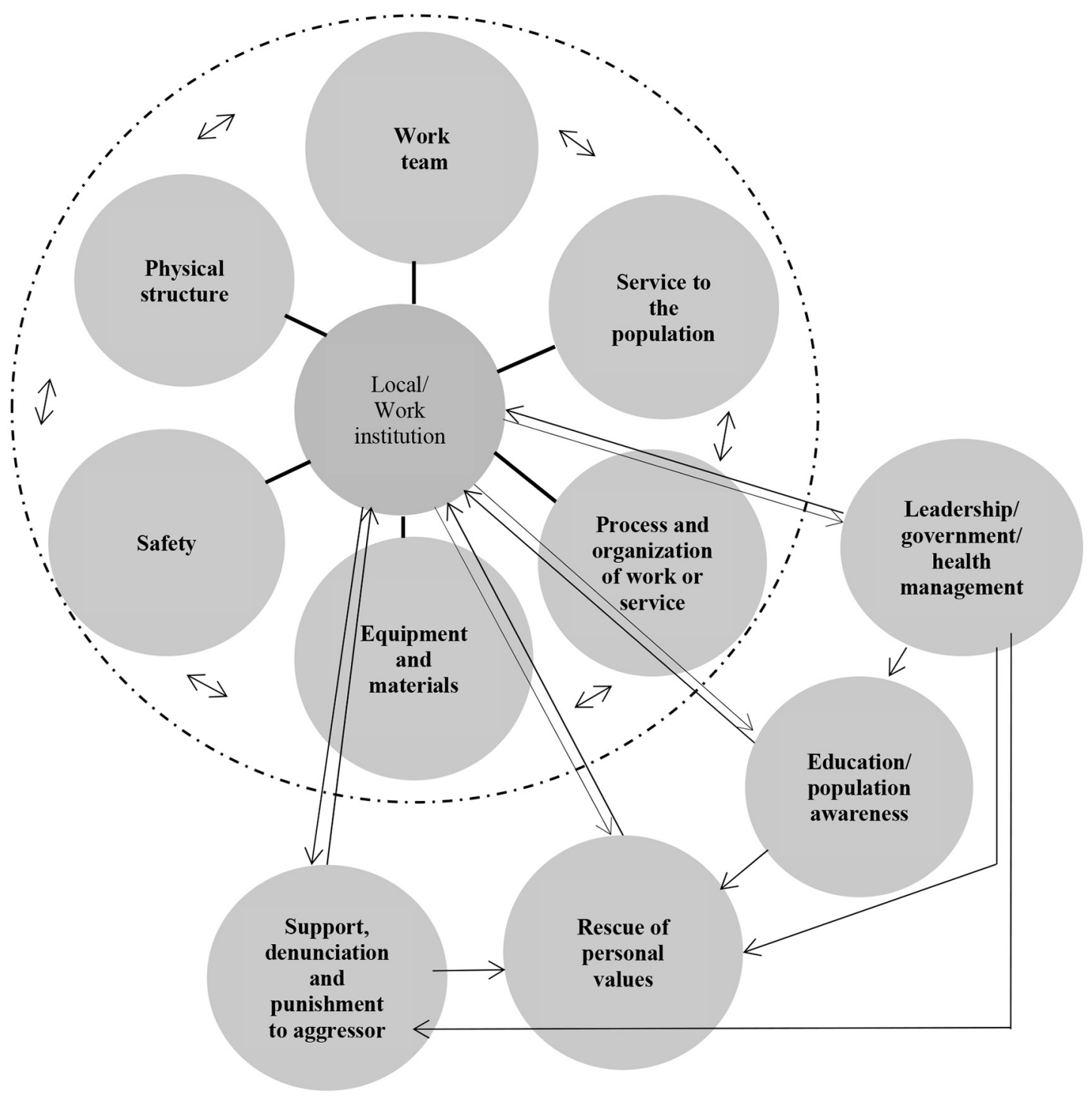

Figure 2 - Model for preventing or reducing workplace violence in health services. Campinas/SP, Chapecó/SC, 2015 to $2017(n=223)$

Source: The Authors, 2015-2017.

The model gathers in dimensions a set of strategies for preventing workplace violence. These strategies are presented in greater detail in Chart 1 and represent the opinion of professionals. The dimensions are ordered in descending order in relation to the number of references. As for the strategies, the most indicated were: to increase the number of workers, to reduce the waiting time for assistance / to reduce the overcrowding of the unit / greater agility in assistance and to improve workplace safety. 


\begin{tabular}{|c|c|}
\hline Dimension & Strategies \\
\hline $\begin{array}{l}\text { Workplace } \\
\text { Safety }\end{array}$ & $\begin{array}{l}\text { Promoting workplace safety: installing video cameras; identify people } \\
\text { (identification badges); presence of trained security professionals and in an adequate } \\
\text { number to regulate entry and exit and the flow of people for } 24 \text { hours, preferably } \\
\text { armed, committed to their duties and who are not limited to the function of } \\
\text { patrimonial guards; presence of police security, municipal guard or policing; restrict } \\
\text { the entry of people to the unit's internal environment; adapt the facilities so that } \\
\text { there are environments with greater privacy, in terms of contact with the public; } \\
\text { implement safety measures at the service location and protection to professionals. }\end{array}$ \\
\hline $\begin{array}{l}\text { Work } \\
\text { Team }\end{array}$ & $\begin{array}{l}\text { Team composition: adjust the number of workers to have a complete team, with } \\
\text { emotionally qualified people and with defined duties; improve the distribution of } \\
\text { personnel and resize the multidisciplinary team. } \\
\text { Interpersonal relationships: resolving disagreements and improving the } \\
\text { interprofessional relationship, including between headship and professionals. } \\
\text { Professional training: training professionals to exercise their functions; train } \\
\text { with respect to workers'rights, improved public service, adequate ways to face or } \\
\text { overcome insults and to handle conflicting situations. } \\
\text { Work performance: directing the team to promote teamwork, commitment } \\
\text { to work, responsibility and respect, and compliance with institutional duties and } \\
\text { standards in accordance with ethical and moral principles. } \\
\text { Worker's health: improve the reception in relation to the worker's health (support } \\
\text { groups, therapeutic listening, psychological assistance and others), decrease the level } \\
\text { of stress and promote the professionals'self-esteem. }\end{array}$ \\
\hline Service to the population & $\begin{array}{l}\text { Quality of care services: reduce waiting times and streamline care, reducing } \\
\text { overcrowding of the service; keep patients and family members informed about the } \\
\text { care and situation of services in the unit; provide humanized, welcoming, responsible, } \\
\text { dialogic care and with respect to the patient and family; improve the facilities and } \\
\text { the process so that the service is able to provide service to people who use it, } \\
\text { without overcrowding. }\end{array}$ \\
\hline $\begin{array}{l}\text { Process and organization } \\
\text { of work or service }\end{array}$ & $\begin{array}{l}\text { Working conditions: improving working conditions. } \\
\text { Service organization: organize the service and its routines; systematize work; } \\
\text { reduce the workload; make the service more resolute, agile and efficient in solving } \\
\text { problems; improve the flow care, inserting a flow aimed at patients; improve the } \\
\text { quality of the workplace environment and the work process, with definition of } \\
\text { guidelines or standards for patients and professionals; recognize the reality of } \\
\text { the workplace to provide targeted actions and plan in order to achieve effective } \\
\text { service; organize the scale of professionals according to the unit's demands; work } \\
\text { together with other sectors, such as social assistance; sensitize service teams that } \\
\text { communicate with each other so that violence is not practiced. }\end{array}$ \\
\hline
\end{tabular}

Chart 1 - Strategies for preventing or reducing workplace violence in health services. Campinas/SP, Chapecó/SC, 2015 a $2017(n=223)$ 


\begin{tabular}{|c|c|}
\hline Dimension & Strategies \\
\hline $\begin{array}{l}\text { Education/ } \\
\text { population awareness }\end{array}$ & $\begin{array}{l}\text { Guide people regarding the flow care in public health, the functioning of the health } \\
\text { system and the unit (institutional regulation), the attributions of each service at } \\
\text { different levels of care, the rights of the population, the responsibilities of health } \\
\text { services and their professionals and about the existence of punishment for contempt } \\
\text { and workplace violence (publicize laws and the topic) through letters, radio, television } \\
\text { and others; sensitize the public that the provision of care with excellence does not } \\
\text { depend only on the professional team; promote the valorization of Primary Health } \\
\text { Care and health professionals. }\end{array}$ \\
\hline Physical structure & $\begin{array}{l}\text { Improve the physical structure of the unit, with airy rooms, a cozy waiting room, more } \\
\text { space and better accommodation for patients. }\end{array}$ \\
\hline Rescue of values & $\begin{array}{l}\text { Promote the professional recognition of health teams; rescue education and respect } \\
\text { between individuals, specifically in contact with health professionals. }\end{array}$ \\
\hline $\begin{array}{l}\text { Leadership/ government/ } \\
\text { health management }\end{array}$ & $\begin{array}{l}\text { Expansion of health services: have sufficient units and hospital beds to provide } \\
\text { the population with the necessary care. } \\
\text { Investment in services and public policies: promote the quality of health } \\
\text { services that integrate the primary and secondary levels of health care, as well } \\
\text { as the excellence of the assistance provided by public services; invest in public } \\
\text { health policies. }\end{array}$ \\
\hline $\begin{array}{l}\text { Support, denunciation } \\
\text { and punishment } \\
\text { to aggressor }\end{array}$ & $\begin{array}{l}\text { Support: support from managers in relation to workers. } \\
\text { Denunciation: encourage the reporting of cases of workplace violence, providing } \\
\text { security for its realization or communication of the fact. } \\
\text { Punishment: to exist punishments for the aggressor and they are applied, regardless } \\
\text { of their hierarchical position. }\end{array}$ \\
\hline Equipment & $\begin{array}{l}\text { Availability and quality of equipment and materials: provide equipment } \\
\text { and materials of quality and in sufficient quantity, and perform maintenance } \\
\text { of equipment. }\end{array}$ \\
\hline
\end{tabular}

Chart 1 - Cont.

Source: Research data, 2015-2017.

\section{DISCUSSION}

In the study it was revealed that more than half of the nursing professionals indicated that they had suffered workplace violence in the previous year, and in some cases, the professionals were exposed to more than one type of violence. Among the three types of violence studied, verbal abuse was the most prevalent, in the same way as in other studies with nurses from emergency sectors ${ }^{(15-16)}$.

There have been reports of experience of violence by professionals of different age groups and generations, especially among younger workers. This context may reflect possible differences in the understanding of how workplace violence is characterized due to generational factors ${ }^{(14)}$, schooling or professional education. Thus, the need for reflections on ethical issues and diversity in the process of training professionals and updates is evident ${ }^{(9)}$. Such approach is also relevant considering that many professionals are vulnerable to violence caused by patients and companions, but there are also those who have suffered or suffer violence from their co-workers, which can impose difficulties for the provision of quality care ${ }^{(17)}$. The potentially harmful effects of violence on stress, health and well-being of professionals point in this same direction ${ }^{(1-2,5-9)}$.

In the literature on workplace violence, the victim's gender is among the variables that have been analyzed ${ }^{(18-19)}$. Studies demonstrate that women and men may be more or less susceptible to certain types of violence and feelings 
about events (the feeling of danger and loneliness can be different) ${ }^{(18-19)}$. In the present study, all reported cases of sexual harassment at work were practiced towards women, and most of them were perpetrated by men.

Regarding to prevention, the adequate number of professionals to provide health care is a strategy that can contribute to speeding up care and reducing overcrowding in the unit's spaces, considering that the prolonged waiting time is one of the factors that has contributed for the occurrence of violence at work in health facilities, in addition to the availability in terms of structure, equipment and materials $s^{(4)}$.

The adequate dimensioning of professionals in the unit can also contribute to reduce tiredness, irritation or similar emotional responses associated with the professional's responsibility to care for a greater number of patients ${ }^{(9)}$. Under the influence of these emotional responses and stress, workers can act in a way that exposes them to violence ${ }^{(2,4,9)}$. Thus, strategies that reduce stress and make it possible to promote social support in the workplace are recommended for preventing violence ${ }^{(2)}$. As well, the promotion of emotional competence in the team has been suggested to reduce stress and prevent workplace violence ${ }^{(9)}$.

In California, in the United States, there is a legislation which has required health institutions the implementation of strategies to prevent workplace violence, including training of personnel, identification of cases and mitigation of risk factors ${ }^{(20)}$. The occupational nurse and his occupational health team play an important role in helping the institutions to meet these requirements, including the training of the health team ${ }^{(20)}$.

In fact, initiatives to prevent workplace violence are necessary to ensure protection for health professionals and offer them an environment and conditions to make them feel safe and respected at work. Although this research has limitations - such as the use of measuring instruments with psychometric properties not yet known and the possibility of memory bias ${ }^{(10)}$ - it stood out situations of workplace violence against nursing professionals, their characteristics and associations, in addition to possible preventive measures, which can guide the development of protective strategies or protocols in this theme.

\section{CONCLUSIONS}

The number of professionals who reported having suffered violence in the 12 months prior to the study exceeded half of the sample, and some suffered more than one type of violence among the three forms analyzed: verbal abuse, sexual harassment and physical violence. Workplace violence was associated with personal, health and work variables, indicating factors to be analyzed from the point of view of their occurrence and understanding of the facts. Different measures on how to avoid workplace violence were listed by professionals and constituted a model capable of encouraging initiatives to prevent this violence in healthcare establishments.

\section{REFERENCES}

1. Fernandes $H$, Sala DCP, Horta ALM. Violence in health care settings: rethinking actions. Rev Bras Enferm. 2018;71(5):2599-601. doi: https://doi. org/10.1590/0034-7167-2017-0882

2. Magnavita N. Workplace violence and occupational stress in healthcare workers: a chicken-and-egg situation-results of a 6-year follow-up study. J Nurs Scholarsh. 2014;46(5):366-76. doi: https://doi.org/10.1111/jnu.12088

3. Dal Pai D, Sturbelle ICS, Santos C, Tavares JP, Lautert L. Physical and psychological violence in the workplace of healthcare professionals. Texto Contexto Enferm. 2018;27(1):e2420016. doi: https://doi. org/10.1590/0104-07072018002420016

4. Angland S, Dowling M, Casey D. Nurses' perceptions of the factors which cause violence and aggression in the emergency department: a qualitative study. Int Emerg Nurs. 2014;22(3):134-9. doi: https://doi.org/10.1016/j. ienj.2013.09.005

5. Vieira GLC. Agressão física contra técnicos de enfermagem em hospitais psiquiátricos. Rev Bras Saúde Ocup. 2017;42:e8. doi: https://doi. org/10.1590/2317-6369000004216

6. Bordignon $\mathrm{M}$, Monteiro Ml. Violence in the workplace in nursing: consequences overview. Rev Bras Enferm. 2016;69(5):996-9. doi: https://doi. org/10.1590/0034-7167-2015-0133

7. Lanctôt N, Guay S. The aftermath of workplace violence among healthcare workers: a systematic literature review of the consequences. Aggress Violent Behav. 2014;19(5):492-501. doi: https://doi.org/10.1016/j.avb.2014.07.010

8. Liu J, Zheng J, Liu K, Liu X, Wu Y, Wang J, et al. Workplace violence against nurses, job satisfaction, burnout, and patient safety in Chinese hospitals. Nurs Outlook. 2019;67(5):558-66. doi: https://doi.org/10.1016/j. outlook.2019.04.006

9. Littlejohn P. The missing link: using emotional intelligence to reduce workplace stress and workplace violence in our nursing and other health care professions. J Prof Nurs. 2012;28(6):360-8. doi: https://doi.org/10.1016/j. profnurs.2012.04.006

10. Bordignon M, Monteiro MI. Predictors of nursing workers' intention to leave the work unit, health institution and profession. Rev Latino-Am Enfermagem. 2019;27:e3219. doi: https://doi.org/10.1590/1518-8345.3280.3219

11. Monteiro I. Questionário de dados sociodemográficos, estilo de vida e aspectos de saúde e trabalho - QSETS: duas décadas. In: Monteiro I, Iguti AM, organizadores. Trabalho, saúde e sustentabilidade: diálogo interdisciplinar internacional Sul - Norte. Campinas: BFCM-Unicamp; 2017 [cited 2019 Sep 10]. Available from: https://econtents.bc.unicamp.br/omp/index.php/ebooks/ catalog/view/19/19/69-1

12. Bordignon M, Monteiro Ml. Apparent validity of a questionnaire to assess workplace violence. Acta Paul Enferm. 2015;28(6):601-8. doi: https://doi. org/10.1590/1982-0194201500098 
13. Reeves TC, Eunjung Oh. Generational Differences. In: Spector JM, Merrill MD, van Merriënboer J, Driscoll MP. Handbook of research on educational communications and technology. Abingdon: Routledge; 2007.

14. Leiter MP, Price SL, Spence Laschinger HK. Generational differences in distress, attitudes and incivility among nurses. J Nurs Manag. 2010;18(8):970-80. doi: https://doi.org/10.1111/j.1365-2834.2010.01168.x

15. Alyaemni A, Alhudaithi H. Workplace violence against nurses in the emergency departments of three hospitals in Riyadh, Saudi Arabia: a cross-sectional survey. NursingPlus Open. 2016; 2:35-41. doi: https://doi.org/10.1016/j. npls.2016.09.001

16. ALBashtawy M. Workplace violence against nurses in emergency departments in Jordan. Int Nurs Rev. 2013;60(4):550-5. doi: https://doi.org/10.1111/ inr.12059

17. Woelfle CY, McCaffrey R. Nurse on nurse. Nurs Forum. 2007;42(3):123-31. doi: https://doi.org/10.1111/j.1744-6198.2007.00076.x

18. Ramacciati N, Ceccagnoli A, Addey B. Violence against nurses in the triage area: an Italian qualitative study. Int Emerg Nurs. 2015;23(4):274-80. doi: https:// doi.org/10.1016/j.ienj.2015.02.004

19. Al-Omari H. Physical and verbal workplace violence against nurses in Jordan. Int Nurs Rev. 2015;62(1):111-8. doi: https://doi.org/10.1111/inr.12170
20. Gooch PP. Hospital workplace violence prevention in California: new regulations. Workplace Health Saf. 2018;66(3):115-9. doi: https://doi. org/10.1177/2165079917731791

\section{Note:}

Paper extracted from the doctoral dissertation "Work ability, violence and intentions to leave among nursing workers", presented to University of Campinas, School of Nursing, Campinas, SP, Brazil.

\section{Acknowledgments:}

This study was supported by: grant \#2016/06128-7, São Paulo Research Foundation/Fundação de Amparo à Pesquisa do Estado de São Paulo (FAPESP); grant \#162825/2014-5, National Council for Scientific and Technological Development/Conselho Nacional de Desenvolvimento Científico e Tecnológico (CNPq); and grant \#01-P-3481/2014, Coordination for the Improvement of Higher Education Personnel/Coordenação de Aperfeiçoamento de Pessoal de Nivel Superior (CAPES).

\section{- Corresponding author:}

Maiara Bordignon

E-mail: bordignonmaiara@gmail.com

Associate editor:

\section{Editor-in-chief:}

Maria da Graça Oliveira Crossetti 